\title{
Analysis of potential drug interactions and adverse reactions to nonsteroidal anti-inflammatory drugs among the elderly
}



Abstract

Objective: The aim of the present study was to analyze potential drug interactions and adverse reactions to NSAIDs in elderly users of a private drug distribution service. Method: A prospective, exploratory and descriptive study with a quantitative approach was performed. The elderly users of NSAIDs attended by the service were interviewed and their prescriptions analyzed between May and September, 2014. Analysis of drug interactions was performed through computerized databases. The post-sales analysis of adverse reactions was performed using the Adverse Drug Reaction Probability Scale. Statistical analysis was performed with the Chi-squared and Fisher's Exact tests. Results: The study evaluated 200 elderly persons, among whom women predominated (56.5\%). The average age was 65 years \pm 10 . The NSAIDs accounted for $38.7 \%$ of prescription drugs used, and included dipyrone (26.9\%), nimesulide (22.8\%) and ketoprofen $(16.3 \%)$. A total of $8.5 \%$ of such drugs were considered inappropriate medications for the elderly. A total of 104 potential drug interactions were identified, of which $24 \%$ were considered highly clinically significant. The NSAIDs with the greatest risk of interactions were ketoprofen $46.2 \%$, ketorolac $14.4 \%$, nimesulide $12.5 \%$ and diclofenac $9.6 \%$. In post-sales monitoring $30.5 \%$ of the elderly persons reported undesirable symptoms after the use of NSAIDs, with stomach discomfort the most prevalent (17\%). Conclusion: The present study confirmed the importance of monitoring the use of NSAIDs among the elderly due to the increased risk of drug interactions and adverse reactions associated with age, concomitant diseases, multi- prescriptions and polypharmacy. The choice of appropriate drugs for the elderly, the reconciliation of all the medications taken by the patient, and effective pharmaceutical care are measures that can contribute to the rational and safe use of NSAIDs.

\footnotetext{
Faculdade Regional de Medicina de São José do Rio Preto - Famerp, Programa de Mestrado em Enfermagem. São José do Rio Preto, São Paulo, Brasil.

2 Faculdade Regional de Medicina de São José do Rio Preto - Famerp, Programa de Doutorado em Ciências da Saúde. São José do Rio Preto, SP, Brasil.

3 Centro Universitário de Rio Preto - Unirp, Departamento de Farmácia. São José do Rio Preto, SP, Brasil.

4 Centro Universitário de Rio Preto - Unirp, Curso de Farmácia. São José do Rio Preto, SP, Brasil

Instituto Evandro Chagas, Laboratório de Pesquisa Básica em Malária. Ananindeua, PA, Brasil.

6 Faculdade de Medicina de São José do Rio Preto - Famerp, Departamento de Cardiologia e Cirurgia Cardiovascular. São José do Rio Preto, SP, Brasil.

Key words: Elderly; Nonsteroidal Antiinflammatory Drugs; Drug Interactions; Drug-Related Side Effects and Adverse Reactions. 


\section{INTRODUCTION}

The increase in drug consumption among the elderly population is due to the prevalence of chronic diseases, the physiology of aging, the influence of the pharmaceutical industry on prescriptions and the medicalization that is common in the training of health professionals. ${ }^{1,2}$ Brazilian studies of this group of patients indicate a mean drug consumption of two to four drugs per elderly individual..$^{3-6}$

The consequences of polypharmacy have a direct impact on clinical, diagnostic, therapeutic and pharma-economic environments. These factors can be reflected in the patient's quality of life and health-related expenditure. The pharmacokinetics/ pharmacodynamics of drugs and the physiological conditions associated with the aging process (decreased production of gastric juice, slower gastric emptying, lower total water content, higher total adipose tissue content, fewer plasma proteins, decreased kidney irrigation, glomerular filtration and tubular secretion, reduced blood flow and enzyme activity in the liver, among others) may lead to a greater prevalence of adverse reactions to drugs and drug and food interactions. ${ }^{6}$

The risk of adverse reactions to drugs (ARDs) is $13 \%$ when an individual consumes two drugs, $58 \%$ for those who use five drugs and $82 \%$ among those who consume seven or more drugs. ${ }^{7}$ Approximately $15 \%$ of hospital admissions caused by ARDs are the result of drug interactons. ${ }^{8}$ The risk of drug interactions is higher among the elderly population due to the prevalence of polytherapy and the number of doctors that assess a single individual. ${ }^{5}$

Drug interactions, whether pharmacokinetic or pharmacodynamic, can lead to positive or negative effects, with an enhanced, decreased or null action. They can even cause toxic reactions. Analysis can predict possible drug interactions, although scientific proof depends on dosedependent reactions and clinical signs that are compatible with the pharmacological action, as well as a laboratorial profile.,
The aim of the present study was to analyze potential drug interactions and adverse reactions to non-steroidal anti-inflammatories (NSAIs) among elderly users of a private drug distribution service.

\section{METHODS}

This was a prospective, exploratory and descriptive study with a quantitative approach. The sample contained individuals aged 60 years or more who had obtained a prescription for at least one NSAI between May and September of 2014.

The patients were interviewed in a private pharmacy in the city of São José do Rio Preto (São Paulo, Brazil) after they had signed a free and informed consent form. In order to ensure the confidentiality of the elderly individuals involved in this research, sequential numerical codes were used for each individual in all stages of the investigation.

A multi-professional health team containing Pharmacy course lecturers who were also students in the Masters and Doctorate programs of the Faculdade de Medicina de São José do Rio Preto (the São José do Rio Preto Medicine School) (FAMERP) collected sociodemographic, clinical and pharmacotherapeutic data using a standardized questionnaire. The interviews were conducted by Pharmacy students from the Centro Universitário de Rio Preto (University Center of Rio Preto) (Unirp), under the supervision of the lecturers who coordinated the project.

The following sociodemographic variables were analyzed: gender; age; marital status; education and place of origin. The clinical data involved the diagnostic assessment of diabetes mellitus and systemic arterial hypertension (SAH). These two illnesses were selected based on their high prevalence among the elderly population. ${ }^{2,3,5}$

The analysis of NSAI prescriptions included the following: the total number of drugs used by the patients during the week of the study; drug combinations containing NSAIs; and the use of NSAIs found on the list of drugs that 
are inappropriate for elderly individuals. ${ }^{3,10,11}$ Acetylsalicylic acid (ASA) was not considered an NSAI when it was prescribed at a daily dose of $100 \mathrm{mg}$ and used as an antiplatelet. Despite their weak anti-inflammatory action (and stronger analgesic and antipyretic action), paracetamol and dipyrone are considered NSAIs due to the fact that they inhibit cyclooxygenase-1 (COX-1) and cyclooxygenase-2 (COX-2). These enzymes are involved in the synthesis of prostaglandins, and consequently were included in the analysis of the present study. ${ }^{12}$

The analysis of adverse reactions to drugs was performed through post-sales monitoring and telephone contact. Once the NSAI was no longer being used, the adverse drug reaction probability scale was applied to determine the causality of specific reactions. This test was selected as it is simple and practical and has been previously validated..$^{13,14}$

The analysis of drug interactions was conducted in three computerized databases: the Drug Interaction Checker (Medscape): ${ }^{15}$ Truven Health Analytics (Micromedex) ${ }^{16}$ and the Drug Interaction Checker (Drugs Information Online). ${ }^{17}$ The Vade Mecum database was used to analyze interactions related to dipyrone and nimesulide, neither of which are available in the abovementioned databases. ${ }^{18}$ Drug interactions were classified according to their intensity: low or non-significant (may alter the patients clinical condition but there is no need to modify the therapeutic strategy); moderate or significant (worsen the clinical condition of the patient and the drug therapy should be analyzed and modified); and severe (potentially severe or fatal affects that may weaken the patient's clinical condition and immediate medical intervention is needed). In cases that involved different classifications of intensity in different databases, the highest level of intensity was adopted.

Descriptive statistical analysis was used to characterize the sociodemographic, clinical and pharmacotherapeutic profile of the participants in the present study. Continuous variables with a normal distribution were presented using mean and standard deviation values. The categorical variables were displayed using numbers and proportions (\%), which were assessed using the Chi-squared test or Fisher's exact test. In the $2 \times 2$ contingency tables, expected values of less than five and small samples can affect the approximation of the distribution of the chi-squared test. In these cases, the Chisquared test was not suitable and was replaced by Fisher's exact test. In all tests, the level of statistical significance was set at $p<0.05$. BioEstat software (version 5.0) was used for the analysis.

The present study received approval from the Research Ethics Committee of the Centro Universitário de Rio Preto under protocol number CAAE: 30768614.1.0000.5604 and was in accordance with Resolution 466/2012 of the National Health Council. The research was also approved by the management of the pharmacy where the data was collected.

\section{RESULTS}

The sample contained 200 elderly individuals, with 113 (56.5\%) women and $87(43.5 \%)$ men. The mean age of the participants was $65 \pm 10$ years, with a minimum age of 60 years and a maximum age of 96 years. Most of the participants were married $(\mathrm{n}=162 ; 81 \%)$, followed by divorced $(\mathrm{n}=21 ; 10.5 \%)$. Concerning their education levels, 33.5\% ( $\mathrm{n}=67$ ) of the participants had completed high school and 31.5\% ( $\mathrm{n}=63)$ had not, while $19(9.5 \%)$ had completed a higher education course. Concerning their place of origin, $192(96 \%)$ resided in the urban zone of the municipality of São José do Rio Preto (Sao Paulo). In terms of clinical condition, $47(23.5 \%)$ were being treated for SAH and 19 (9.5\%) had type 2 diabetes mellitus. Table 1 displays this data.

The 200 prescriptions that were analyzed prescribed 760 drugs, of which 294 (38.7\%) were NSAIs (Table 2). 
Table 1. Sociodemographic and clinical characteristics of 200 elderly users of a commercial pharmacy. São José do Rio Preto-SP, 2014.

\begin{tabular}{|c|c|c|}
\hline Variable & $\mathrm{n}$ & $\%$ \\
\hline \multicolumn{3}{|l|}{ Gender } \\
\hline Female & 113 & 56.5 \\
\hline Male & 87 & 43.5 \\
\hline Age (mean and standard deviation) & \multicolumn{2}{|c|}{$65 \pm 10$ years } \\
\hline \multicolumn{3}{|l|}{ Marital status } \\
\hline Married & 162 & 81.0 \\
\hline Divorced & 21 & 10.5 \\
\hline Single & 3 & 1.5 \\
\hline Widow & 14 & 7.0 \\
\hline \multicolumn{3}{|l|}{ Education } \\
\hline Higher level complete & 19 & 9.5 \\
\hline Higher level incomplete & 3 & 1.5 \\
\hline High school complete & 67 & 33.5 \\
\hline High school incomplete & 17 & 8.5 \\
\hline Primary school complete & 31 & 15.5 \\
\hline Primary school incomplete & 63 & 31.5 \\
\hline \multicolumn{3}{|l|}{ Origin } \\
\hline Urban zone & 192 & 96.0 \\
\hline Rural zone & 8 & 4.0 \\
\hline \multicolumn{3}{|l|}{ Clinical condition } \\
\hline Arterial hypertension & 47 & 23.5 \\
\hline Diabetes mellitus & 19 & 9.5 \\
\hline
\end{tabular}


Table 2. Distribution of the 294 non-steroidal anti-inflammatories prescribed on the 200 prescriptions for elderly users of a pharmacy. São José do Rio Preto-SP, 2014.

\begin{tabular}{lcc}
\hline \multicolumn{1}{c}{ Generic name } & $\mathrm{N}$ & $\%$ \\
\hline Dipyrone & 79 & 26.9 \\
Nimesulide & 67 & 22.8 \\
Ketoprofen & 48 & 16.3 \\
Paracetamol & 36 & 12.2 \\
Ketorolac & 27 & 9.2 \\
Diclofenac & 17 & 5.8 \\
Ibuprofen & 9 & 3.1 \\
Piroxicam & 6 & 2.0 \\
Meloxicam & 3 & 1.0 \\
Celecoxib & 2 & 0.7 \\
\hline Total & 294 & 100 \\
\hline
\end{tabular}

The mean number of drugs per prescription was 3. Among the NSAIs, 69 drugs (23.5\%) were prescribed under their generic name. In total, $126(42.9 \%)$ were not on the list of drugs that are standardized in the municipality. Only $26(13 \%)$ patients did not know why the NSAI had been prescribed. The most common reasons for the prescription of NSAIs were: rheumatic problems (21\%); throat pain (12\%); odontological treatment $(12 \%)$ and backache (7.5\%). Only one prescription prescribed an injectable NSAI containing a combination of dipyrone, adiphenine hydrochloride and promethazine hydrochloride. Three NSAIs belonged to the list of controlled substances, ${ }^{19}$ composed of the following associations: (1) paracetamol and codeine; (2) tramadol and paracetamol; and (3) celecoxib in isolation. Seven NSAIs were prescribed in the form of a drug combination (usually dipyrone and paracetamol), with other main active ingredients.

Of the NSAIs prescribed, $8.5 \%(\mathrm{n}=25)$ were on the list of drugs that are inappropriate for the elderly, including ketoprofen $(\mathrm{n}=14 ; 56 \%)$, piroxicam $(n=6 ; 24 \%)$, meloxicam $(n=3 ; 12 \%)$ and naproxen $(\mathrm{n}=2 ; 8 \%)$.

Of the 200 prescriptions analyzed, 65 (32.5\%) contained two drugs and 81 (40.5\%) contained three drugs, while other quantities were less common. Potential drug interactions were identified in 89 $(44.5 \%)$ prescriptions, giving a total of 104 potential drug interactions, which were most common on prescriptions containing either three $(\mathrm{n}=36)$ or two $(\mathrm{n}=22)$ drugs. This data is displayed in Table 3. 
Table 3. Number of drugs per prescription and the frequency of potential drug interactions in the analysis of 200 prescriptions for elderly individuals. São José do Rio Preto-SP, 2014.

\begin{tabular}{cccccc}
\hline $\begin{array}{c}\text { Number of drugs } \\
\text { per prescription }\end{array}$ & $\begin{array}{c}\text { Prescriptions } \\
\text { with } \\
\text { interactions }\end{array}$ & $\begin{array}{c}\text { Prescriptions without } \\
\text { interactions }\end{array}$ & $p$ & $\mathrm{n}$ & $\%$ \\
\hline 2 & 22 & 43 & $0.1714^{*}$ & 65 & 32.5 \\
3 & 36 & 45 & $0.0901^{*}$ & 81 & 40.5 \\
4 & 18 & 17 & $0.5650^{*}$ & 35 & 17.5 \\
5 & 4 & 4 & $0.9555^{* *}$ & 8 & 4.0 \\
6 & 4 & 1 & $0.2626^{* *}$ & 5 & 2.5 \\
7 & 3 & 1 & $0.4799^{* *}$ & 4 & 2.0 \\
8 & 2 & 0 & $0.3922^{* *}$ & 2 & 1.0 \\
\hline Total & 89 & 111 & & 200 & 100.0 \\
\hline
\end{tabular}

*Chi-squared test; ${ }^{* *}$ Fisher's exact test.

Potential drug interactions were described in $28(59.6 \%)$ of the 47 patients with hypertension $(p=0.1169$; chi-squared) and in 56 of the 153 patients without hypertension. Nine (47.4\%) patients with type 2 diabetes mellitus exhibited potential drug interactions $(p=0.7752$; chisquared), whereas 69 of the 181 participants without diabetes exhibited potential drug interactions. No significant associations were found between these two illnesses and drug interactions.
Concerning the intensity of the 104 potential drug interactions, 24\% $(n=25)$ were classified as high or severe, with $40.4 \%(n=42)$ classified as moderate and $22.1 \%(\mathrm{n}=23)$ classified as low. A further $13.5 \%(n=14)$ were not classified by the databases used herein. The NSAIs with the greatest risk of drug interactions were ketoprofen $(\mathrm{n}=48 ; 46.2 \%)$, ketorolac $(\mathrm{n}=15 ; 14.4 \%)$, nimesulide $(\mathrm{n}=13 ; 12.5 \%)$ and diclofenac $(\mathrm{n}=10 ; 9.6 \%)$. Table 4 displays the potential drug interactions with the greatest intensity levels. 
Table 4. Most common potential drug interactions in the therapeutic plans of patients, as well as their clinical implications and the databases used. São José do Rio Preto-SP, 2014.

\begin{tabular}{llcccc}
\hline \multicolumn{2}{c}{ Drug interactions } & Database** & \multicolumn{2}{c}{ Patients } \\
$\begin{array}{c}\text { Drug 1 } \\
\text { (NSAI) }\end{array}$ & \multicolumn{1}{c}{ Drug 2 } & Clinical implications & n & $\%$ \\
\hline Ketoprofen & Ketorolac* & Risk of adverse gastrointestinal affects & $1,2,3$ & 6 & 24.0 \\
Ketoprofen & Enoxaparin & Risk of bleeding & $1,2,3$ & 4 & 16.0 \\
Ketoprofen & AAS & Risk of adverse gastrointestinal affects & $1,2,3$ & 3 & 12.0 \\
Piroxicam & Ciprofloxacin & Risk of convulsions & 2,3 & 2 & 8.0 \\
Ketoprofen & Citalopram & Risk of bleeding & $1,2,3$ & 1 & 4.0 \\
Ketoprofen & Clopidogrel & Risk of bleeding & $1,2,3$ & 1 & 4.0 \\
Ketoprofen & Escitalopram & Risk of bleeding & $1,2,3$ & 1 & 4.0 \\
Ketoprofen & Rivaroxaban & Risk of bleeding & $1,2,3$ & 1 & 4.0 \\
Ketorolac & Gabapentin & Reduction in the anticonvulsant affect & 1 & 1 & 4.0 \\
Ketorolac & Cilostazol & Risk of gastrointestinal bleeding & 1,3 & 1 & 4.0 \\
& & & & & \\
Ketorolac & Enoxaparin & Risk of bleeding & $1,2,3$ & 1 & 4.0 \\
Ketorolac & Escitalopram & Risk of bleeding & $1,2,3$ & 1 & 4.0 \\
Diclofenac & Duloxetine & Risk of bleeding & $1,2,3$ & 1 & 4.0 \\
Ibuprofen & Escitalopram & Risk of bleeding & $1,2,3$ & 1 & 4.0 \\
\hline Total & & & & 25 & 100.0 \\
\hline
\end{tabular}

*Interaction between NSAIs; **(1) Micromedex, (2) Medscape, (3) Drugs.

During post-sales drug monitoring, 61 (30.5\%) of the patients reported undesirable symptoms. The most common problems were stomach discomfort, which was reported by $34(17 \%)$ individuals, and nausea, which was mentioned by $11(5.5 \%)$ patients.
The drugs that were most often linked to adverse reactions were nimesulide $(\mathrm{n}=21)$ and ketoprofen $(\mathrm{n}=20)$. None of the undesirable reactions achieved the classification of a defined adverse reaction, despite the fact that several of them were described on the label of the drug containers (Table 5). 
Table 5. Probability of adverse reactions according to the algorithm of Naranjo et al., ${ }^{13}$ reported for 61 patients, with a causal relationship for the use of non-steroidal anti-inflammatories, and the description (or lack of) on the labels of drugs. São José do Rio Preto-SP, 2014.

\begin{tabular}{lcccc}
\hline \multicolumn{1}{c}{ Adverse reaction } & NSAI & $\begin{array}{c}\text { Description on } \\
\text { the label }\end{array}$ & $\begin{array}{c}\text { Causal } \\
\text { relationship }\end{array}$ & $\begin{array}{c}\text { Number of } \\
\text { patients }\end{array}$ \\
\hline Stomach discomfort & Nimesulide & Yes & Probable & 15 \\
Stomach discomfort & Ketoprofen & Yes & Possible & 10 \\
Stomach discomfort & Ketorolac & Yes & Probable & 5 \\
Stomach discomfort & Dipyrone & No & Possible & 4 \\
Nausea & Nimesulide & Yes & Probable & 3 \\
Nausea & Ketorolac & Yes & Probable & 2 \\
Nausea & Ketoprofen & Yes & Possible & 4 \\
Nausea & Ibuprofen & Yes & Possible & 1 \\
Purple stains on the skin & Ketoprofen & No & Probable & 2 \\
Hypotension & Ketorolac & No & Probable & 1 \\
Hypotension & Dipyrone & Yes & Probable & 1 \\
Swelling & Diclofenac & No & Probable & 1 \\
Swelling & Nimesulide & No & Probable & 1 \\
Drowsiness & Meloxicam & Yes & Probable & 1 \\
Drowsiness & Ketoprofen & Yes & Probable & 3 \\
Drowsiness & Nimesulide & Yes & Probable & 2 \\
Heartburn & Ketorolac & No & Probable & 1 \\
Heartburn & Ketoprofen & No & Probable & 1 \\
Constipation & Dipyrone & No & Probable & 1 \\
Burning eyes & Yes & Probable & 2 \\
\hline Total & & & 61 \\
\hline & & & & 2 \\
\hline
\end{tabular}

Of the 61 patients who reported undesirable symptoms, $29(47.5 \%)$ exhibited potential drug interactions. Of the 139 who had no symptoms, $48(34.5 \%)$ exhibited potential drug interactions. No significant differences were found between the presence of interactions and the occurrence of undesirable symptoms ( $p=0.1135$; chi-squared test).

\section{DISCUSSION}

The significant increase in the elderly population is reflected in the health services through the prevalence of chronic and degenerative diseases such as hypertension, diabetes mellitus, coronary diseases, depression and Alzheimer's disease, among others. The elderly are continuous drug users, and consequently, they are exposed to certain risks. ${ }^{1,3,11,20}$

Drug consumption by females represented $56.5 \%$ of the sample studied. Women tend to consume more drugs due to biological reasons, as well as the fact that they are more concerned with health issues and they tend to use health services more frequently. ${ }^{1,3,4,10,11,21}$ 
Education is a relevant factor when analyzing healthcare. A low level of education can lead to difficulties when reading and interpreting the labels on drugs, with the consequent risks of incorrect use and worsening health. ${ }^{5}$ In the present study, $33.5 \%$ of the participants had completed high school. This finding differs from earlier studies, such as a survey in Novo Horizonte (São Paulo), in which $68.6 \%$ of the elderly participants had not completed primary school and $22.1 \%$ were illiterate. ${ }^{4}$ Another study conducted in São Paulo reported that $16.6 \%$ of the participants were illiterate, while $64.1 \%$ had completed between one and seven years of study and $19.3 \%$ had studied for eight or more years..$^{10}$ The mean quantity of drugs per prescription in the present study (4) corroborates the results in literature (between two and five drugs per prescription). ${ }^{1,10}$

Concerning the clinical condition of the participants, 23.5\% were being treated for $\mathrm{SAH}$ and $9.5 \%$ had type 2 diabetes mellitus. A study in São Paulo reported that $44.7 \%$ of the elderly participants had zero or one chronic diseases, while the remainder $(55.3 \%)$ had two or more. ${ }^{10}$ The prevalence of chronic diseases among the elderly leads to the greater consumption of drugs and the consequent increase in the risk of drug interactions and adverse reactions. . $^{7,11}$

Of the 294 NSAIs prescribed, 69 drugs (23.5\%) were prescribed under their generic name and $126(42.9 \%)$ were not on the list of standardized drugs. On the drug prescriptions, the use of the generic name varied between $43 \%$ and $98.7 \%$, while the prescription of standardized drugs ranged between $68.6 \%$ and $99.4 \% .^{1}$ The World Health Organization (WHO) recommends the adoption of generic names on all prescriptions and a minimum prescription of $70 \%$ standardized drugs, considering the individuality of the patient. ${ }^{22}$ The fact that the present study was conducted in a private pharmacy does not rule out the impossibility of access to drugs due to cost. Therefore, it is essential to respect the standardization of drugs when making prescriptions. These results suggest that the list of standardized drugs is not being analyzed at the time of prescription. Thus, the patient may not be taking the drug that they need, which represents a medication-related issue. ${ }^{23}$

Twenty-five $(8.5 \%)$ of the NSAIs prescribed were on the list of inappropriate drugs for the elderly, including ketoprofen, piroxicam, meloxicam and naproxen. This result is higher than a study in São Paulo, which reported that 1.5\% of the NSAIs prescribed were inappropriate for elderly individuals, including piroxicam, naproxen and cetorolaco. ${ }^{10}$ Conversely, other Brazilian studies have found no inappropriate NSAIs on prescriptions for elderly individuals. . $^{311,24}$

NSAIs are most commonly used to treat different inflammatory conditions, as well as to pain and fever without inflammation. ${ }^{25}$ The frequency of use of NSAIs, including non-selective inhibitors (ketoprofen, diclofenac, ibuprofen, paracetamol, meloxicam, piroxicam, among others) and selective COX-2 inhibitors (celecoxib and etoricoxib) has increased in recent years. ${ }^{26}$ The main causes for this increase include the ease of access to drugs, some of which are freely available, and a larger elderly population with concomitant inflammatory diseases. ${ }^{27}$

Among the range of NSAIs used, the present study confirmed $38.7 \%$ of them on the prescriptions, with a predominance of dipyrone $(26.9 \%)$, followed by nimesulide $(22.8 \%)$ and ketoprofen (16.3\%). Another Brazilian study also reported that dipyrone was the most commonly prescribed drug of this class among the elderly. ${ }^{1}$ Conversely, other national and international studies have cited the following NSAIs as the most common on prescriptions: ibuprofen $(58.6 \%$ and $19.2 \%) ;{ }^{21,25}$ diclofenac $(50 \%) ;{ }^{28}$ naproxen $(78.3 \%) ;{ }^{29}$ and ibuprofen, naproxen, ketoprofen and flurbiprofen $(29.7 \%) .{ }^{30}$

NSAIs are responsible for between 20 to $25 \%$ of all ARDs. ${ }^{28}$ NSAIs that are non-selective for cyclooxygenase inhibit the production of prostaglandins in the gastrointestinal mucosa, which can cause abdominal pain and discomfort, gastric ulcers, or even digestive bleeding. COX-2 selective inhibitors are safer in terms of gastric 
problems, although the cardiovascular risk is higher, which has led to several of these drugs being removed from the global drug market. This explains the low rate of prescription for these drugs in the present study, in which celecoxib was only found on two prescriptions. . $^{26,28,31,32}$

Stomach discomfort was the most common undesirable reaction encountered by the participants, with nimesulide and ketoprofen the most common cause. Nimesulide is derived from sulfonanilide and has an analgesic and anti-inflammatory affect. It is used to combat inflammation of the osteoarticular and upper respiratory systems, headaches, myalgia and postsurgical pain. ${ }^{28}$ During its use, gastrointestinal disorders such as nausea and vomiting may occur, which seem to be correlated with the dose and the period of use. Traditional NSAIs exhibit lower rates of gastrointestinal injuries, and as such, they are considered a safe and effective therapeutic option, with satisfactory oral absorption, a fast action, a favorable risk-benefit profile and low renal toxicity. ${ }^{33}$ Ketoprofen is a derivative of propionic acid, similar to ibuprofen and naproxen, which are non-selective cyclooxygenase inhibitors with similar therapeutic effects (and side-effects) to other NSAIs. ${ }^{30,34}$ In the present study, no statistically significant differences were found between the occurrence of undesirable symptoms and the risk of potential drug interactions.

In general, NSAIs can worsen kidney problems, particularly in elderly individuals who suffer from hypertension and diabetes, while also increasing the risk of drug interactions. ${ }^{26,28,31,32}$ In the present study, $23.5 \%$ of the patients using NSAIs suffered from $\mathrm{SAH}$, while $9.5 \%$ had diabetes. However, no statistically significant differences were found between the occurrence of these illnesses and the risk of drug interactions.

In the present study, a total of 124 potential drug interactions were identified among the 204 NSAIs prescribed. Of these interactions, 24\% were classified as high intensity, indicating a greater clinical significance. The use of two drugs involved in an interaction concomitantly is not recommended as the risks generally outweigh the benefits. ${ }^{30}$ The following interactions were classified as high intensity in the present study: NSAI + anticoagulant; NSAI + antiplatelet; NSAI + antidepressant selective serotonin reuptake inhibitors (SSRIs), which were associated with a risk of bleeding. In addition, a significant interaction was recorded between NSAIs and antimicrobials, with a risk of convulsions, and between NSAIs and anticonvulsant drugs, leading to a reduction in the anticonvulsant effect. The most common moderate drug interaction was between NSAIs + anti-hypertensives and diuretics, with a risk of reducing the desired effects. No statistically significant associations were found between the number of drugs prescribed and the risk of drug interactions.

A Portuguese study confirmed the occurrence of 123 moderate drug interactions and two minor interactions, of which $12.8 \%$ involved an interaction between NSAIs and diuretics, angiotensin receptors, calcium channel blockers or angiotensin converting enzyme inhibitors. ${ }^{30} \mathrm{~A}$ systematic review of hypertensive patients and the use of NSAIs identified 21 types of interactions between NSAIs, antihypertensives and diuretics. ${ }^{35}$ However, a Colombian study reported a low proportion of chronic use of NSAIs among patients with a high cardiovascular risk. ${ }^{29}$

The drug interactions confirmed were related to NSAIs and continuous use drugs, such as hematological agents, antidepressants, anticonvulsants, antihypertensives and diuretics. The interactions between NSAIs occurred due to drug duplicity on prescriptions, since some drugs were prescribed in association and in isolation. Examples include: the prescription of ketoprofen in isolation and in association with paracetamol; the prescription of ketoprofen in isolation and diclofenac associated with carisoprodol, paracetamol and caffeine. Potential drug interactions should be assessed by the pharmacist at the time of dispensation. This would lead to the risks to patients being communicated to the doctor who provided the prescription, thereby optimizing pharmacotherapy and ensuring the safety of patients. 
The present study contains a number of limitations, due to the fact that it is a descriptive transversal study. In other words, this investigation did not confirm the occurrence of possible problems related to the drugs prescribed, such as adverse reactions and drug interactions, through prolonged systematic monitoring. Future studies should involve continuous monitoring of the study group to assess the incidence of clinical occurrences related to pharmacotherapy using continuous pharmaceutical care projects.

\section{CONCLUSION}

The data obtained in the present study enabled us to identify the prescription profile of non-steroidal anti-inflammatories in a sample of elderly individuals who used a private drug distribution service. The importance of monitoring the use of these drugs was confirmed, given the high potential for drug interactions and adverse reactions among elderly individuals who take them. These patients usually have concomitant chronic diseases, such as systemic arterial hypertension and diabetes mellitus, and are polymedicated, which involves consultations with more than one specialist. These factors favor the occurrence of drug interactions and adverse reactions to drugs. It is the responsibility of the pharmacist to identify these problems, as they have contact with the patients during the final cycle of medication (dispensation). The occurrence of these problems could be reduced by identification and preventive measures, thereby ensuring the safer (and more rational) use of these drugs.

\section{REFERENCES}

1. Maschio-Lima TA, Nakazone MA, Furini AAC. Avaliação preliminar de prescrições para idosos em serviço de cardiologia de um hospital de ensino. Rev Bras Cardiol 2014;27(5):333-41.

2. Santos MB, Ribeiro SA. Dados sociodemográficos e condições de saúde de idosas inscritas no PSF de Maceió, AL. Rev Bras Geriatr Gerontol 2011;14(4):613-23.

3. Ribas C, Oliveira KR. Perfil dos medicamentos prescritos para idosos em uma Unidade Básica de Saúde do município de Ijuí-RS. Rev Bras Geriatr Gerontol 2014;17(1):99-114.

4. Furini AAC, Maschio-Lima TA, Faitarone NC, Verona JP, Silva LAM, Santos SS, et al. Atenção farmacêutica nas interações medicamentosas e indicadores de prescrição em unidade básica de saúde. Arq Ciênc Saúde 2014;21(2):99-106.

5. Barbosa MT. Os idosos e a complexidade dos regimes terapêuticos. Rev Assoc Med Bras 2009;55(4):364-65.

6. Bueno CS, Oliveira KR, Berlezi EM, Eickhoff HM, Dallepiane LB, Girardon-Perlini, et al. Utilização de medicamentos e risco de interações medicamentosas em idosos atendidos pelo Programa de Atenção ao Idoso da Unijuí. Rev Ciênc Farm Básica Apl 2009;30(3):331-8.
7. Secoli SR. Polifarmácia: interações e reações adversas no uso de medicamentos por idosos. Rev Bras Enferm 2010;63(1):136-40.

8. Varallo FR, Costa MA, Mastroianni PC. Potenciais interações medicamentosas responsáveis por internações hospitalares. Rev Ciênc Farm Básica Apl 2013;34(1):79-85.

9. Passos MMB, Santos RC, Bergamini VG, Souza DC. Interações medicamentosas em pacientes internados na clínica médica de um hospital de ensino e fatores associados. Rev Bras Farm 2012;93(4):450-6.

10. Cassoni TCJ, Corona LP, Romano-Lieber NS, Secoli SR, Duarte YAO, Lebrão ML. Uso de medicamentos potencialmente inapropriados por idosos do Município de São Paulo, Brasil: Estudo SABE. Cad Saúde Pública 2014;30(8):1708-20.

11. Cuentro VS, Andrade MA, Gerlack LF, Bós AJG, Silva MVS, Oliveira AF. Prescrições medicamentosas de pacientes atendidos no ambulatório de geriatria de um hospital universitário: estudo transversal descritivo. Ciênc Saúde Coletiva 2014;19(8):3355-64.

12. Brasil. Ministério da Saúde. Formulário Terapêutico Nacional [Internet]. 2. ed. Brasília, DF: Ministério da Saúde; 2010 [acesso em 15 abr. 2016]. Disponível em: http://bvsms.saude.gov.br/bvs/publicacoes/ formulario_terapeutico_nacional_2010.pdf 
13. Naranjo CA, Busto U, Sellers EM, Sandor P, Ruiz I, Roberts EA, et al. A method for estimating the probability of adverse drug reactions. Clin Pharmacol Ther 1981;30(2):239-45.

14. Visacri MB, Souza CM, Sato CMS, Granja S, Marialva M, Mazzola PG, et al. Adverse Drug Reactions and quality deviations monitored by spontaneous reports. Saudi Pharm J 2014;22(4)283-390.

15. Medscape [Internet]. New York: MD LLC; 1994- . Multi-drug Interaction Checker; 2014 [acesso em nov. 2014]. Disponível em: http://reference.medscape. com/drug-interactionchecker.

16. Micromedex. [place unknown]: Truven Health Analytics; 2014 [acesso em 23 nov. 2014]. Disponível em: http://aplicacao.periodicos.saude.gov.br.

17. Drugs.com. [Internet]. [place unknown]; 2000- . Drug Interactions Checker Drug Information Online; 2014 [acesso em 14 nov. 2014]. Disponível em: http://www. drugs.com/drug_interactions.php

18. P.R. Vade-Mécum [Internet]. Perdizes: GR Publicações; 2014- [acesso em 23 nov. 2014]. Disponível em: http://br.prvademecum.com/

19. Brasil. Portaria n 344 , de 12 de maio de 1998. Aprova o Regulamento Técnico sobre Substâncias e Medicamentos Sujeitos a Controle Especial. Diário Oficial da União, Brasília, 19 mai. 1998, Seção 1.

20. Menezes TN, Sousa NDS, Moreira AS, Pedraza DF. Diabetes mellitus referido e fatores associados em idosos residentes em Campina Grande, Paraíba. Rev Bras Geriatr Gerontol 2014;17(4):829-39.

21. Bandeira VAC, Pai CTD, Oliveira KR. Uso de antiinflamatórios não esteroides por idosos atendidos em uma Unidade de Estratégia de Saúde da Família do município de Ijuí (RS). Rev Bras Ciênc Envelhec Hum 2013;10(2):181-92.

22. World Health Organization, Action Programme on Essential Drugs. How to investigate drug use in health: selected drug use indicators. Geneva: WHO; 1993. (EDM Research Series, no 007. WHO/DAP/93.1).

23. Comité de Consenso. Segundo consenso de Granada sobre problemas relacionados con medicamentos. Ars Pharm 2002;43(3-4):179-87.

24. Stroher A, Zubioli A. Prevalência de medicamentos potencialmente inapropriados para idosos entre os padronizados no Hospital Universitário Regional de Maringá de acordo com os critérios de Beers-Fick. Infarma 2014;26(1):4-10.
25. Osorio A, Otero RW, Gómez ZM. Utilización de AINES y uso de IBP profilácticos en pacientes de medicina interna. Rev Col Gastroenterol 2014;29(2):125-30.

26. Batlouni M. Anti-inflamatórios não esteroides: efeitos cardiovasculares, cérebro-vasculares e renais. Arq Bras Cardiol 2010;94(4):556-63.

27. Melgaço SSC, Saraiva MIR, Lima TTC, Silva GB Júnior, Daher EF. Nefrotoxicidade dos antiinflamatórios não esteroidais. Medicina (Ribeirão Preto) 2010;43(4):382-90.

28. Schallemberger JB, Pletsch MU. Riscos do uso indiscriminado de anti-inflamatórios não esteroidais [Internet]. In: Salão do Conhecimento. 23ํ Seminário de Iniciação Científica; 2014; Ijuí. Ijuí: UNIJUÍ; 2014 [citado em 23 nov. 2014]. Disponível em: https://www.revistas.unijui.edu.br/index.php/ salaoconhecimento/article/view/3490/2890.

29. Machado-Alba JE, Alzate-Carvajal V, EcheverriCataño L. Estudio farmacoepidemiológico de uso de anti-inflamatorios no esteroideos en pacientes de alto riesgo cardiovascular. Rev Peru Med Exp Salud Publica 2013;30(4):626-9.

30. Castel-Branco MM, Santos AT, Carvalho RM, Caramona MM, Santiago LM, Fernandez-Llimos F, et al. As bases farmacológicas dos cuidados farmacêuticos: o caso dos AINEs. Acta Farm Port 2013;2(2):20-7.

31. Areia M, Pereira AD, Banhudoc A, Coutinho G. Non-steroidal anti-inflammatory drugs and gastroprotection gap among Family Physicians: results from a survey. GE J Port Gastrenterol 2013;20(6):243-9.

32. Couto G. Baixa taxa de gastroproteção em doentes de risco sob terapêutica com anti-inflamatórios não esteroides. GE J Port Gastrenterol 2013;20(6):237-9.

33. Oliveira KR, Pereira DC, Coleta CF. Dispensação de anti-inflamatórios, analgésicos e antipiréticos na farmácia-escola da Unijuí. Rev Contexto Saúde 2012;12(23):67-74.

34. Muri EMF, Spotito MMM, Metsavaht L. Nonsteroidal anti-inflammatory drugs and their local pharmacology. Acta Fisiátrica 2009;16(4):186-90.

35. Villa J, Cano A, Franco D, Monsalve M, Hincapié J, Amariles P. Relevancia clínica de las interacciones medicamentosas entre antiinflamatorios no esteroideos y antihipertensivos. Aten Prim 2014;46(9):464-74. 